\title{
ANTIOKSIDAN BIJI KAKAO: PENGARUH FERMENTASI DAN PENYANGRAIAN TERHADAP PERUBAHANNYA (ULASAN)
}

\author{
Cocoa Antioxidant: Effect of Fermentation and Roasting \\ on Antioxidant Change (Review) \\ Ratri Retno Utami \\ Balai Besar Industri Hasil Perkebunan \\ JI. Prof. Abdurahman Basalamah No. 28 Makassar 90231 \\ e-mail: ratri.retno.u@gmail.com
}

\begin{abstract}
The main cocoa antioxidant compounds are flavanols that consist of monomer (epicatechin and catechin) and oligomers from dimers to decamers (procyanidin), with small quantity of anthocyanin (cyanidin glucoside) and flavonol (quercetin glycoside). Cocoa processing stages that affect antioxidant compounds changes are fermentation and roasting. Fermentation causes decrease of polyphenol content due to polyphenols diffusion out of the cotyledons, furthermore polyphenols undergo oxidation and condensation. Roasting temperature more than $70^{\circ} \mathrm{C}$ cause loss of (+)-catechin. During roasting, protein that bounded to the cell wall (cellulose and pectin) undergo Maillard reaction where its products potentially as antioxidants. This study is useful to know the proper of cocoa beans processing so antioxidant content can be maximized. Cocoa beans with good flavor and high antioxidant activity can be obtained through $6^{\text {th }}$ days fermentation and roasting at $110^{\circ} \mathrm{C}$ for 60 minutes.
\end{abstract}

Keywords: cocoa beans, fermentation, roasting, antioxidant

\begin{abstract}
Abstrak Senyawa antioksidan utama pada kakao adalah golongan flavanol berupa monomer (epicatechin dan catechin) serta oligomer dari dimer sampai dekamer (procyanidin), dengan sejumlah kecil anthocyanin (cyanidin glycoside) dan flavonol (quercetin glycoside). Tahapan pengolahan biji kakao yang mempengaruhi perubahan senyawa antioksidan adalah proses fermentasi dan penyangraian. Fermentasi menyebabkan kandungan polifenol turun karena difusi polifenol keluar dari kotiledon selain itu polifenol mengalami oksidasi dan kondensasi. Penyangraian dengan suhu lebih dari $70^{\circ} \mathrm{C}$ menyebabkan kehilangan (+)-catechin. Selama penyangraian, protein yang terikat dengan dinding sel (selulosa dan pektin) akan mengalami reaksi Maillard dimana produk reaksi Maillard berpotensi sebagai antioksidan. Kajian ini bermanfaat untuk mengetahui kondisi proses pengolahan biji kakao yang tepat sehingga aktivitas antioksidan dapat dimaksimalkan. Kondisi pengolahan supaya diperoleh biji kakao yang mempunyai cita rasa baik dan aktivitas antioksidan tinggi adalah dengan fermentasi 6 hari dan penyangraian pada $110^{\circ} \mathrm{C}$ selama 60 menit.
\end{abstract}

Kata Kunci: biji kakao, fermentasi, penyangraian, antioksidan

\section{PENDAHULUAN}

Sel dalam kotiledon biji kakao terdiri dari sel penyimpanan yang mengandung lemak dan protein serta sel pigmen yang mengandung senyawa polifenol. Polifenol biji kakao berupa monomer yaitu epicatechin yang merupakan flavanol utama dengan kandungan sebanyak 34,65-43,27 mg/g (sekitar $35 \%$ dari total fenolik). Flavanol yang lain adalah catechin, gallocatechin dan epigallocatechin (Kim dan Keeney, 1984; Wollgast dan Anklam, 2000). Flavonol pada biji kakao fermentasi terdiri dari quercetin, isoquercitrin (quercetin-3-O-glucoside), quercetin-3-O-arabinoside, quercetin-3-
O-glucuronide, hyperoside (quercetin3-O-galactoside), luteolin, luteolin-7-Oglucoside, apigenin, vitexin (apigenin-8C-glucoside), isovitexin (apigenin-6-Cglucoside), naringenin (Andres-Lacueva et al., 2008), serta catechin-C glycoside (Lau-Cam et al., 2013). Fraksi anthocyanin terdiri dari cyanidin-3- $\alpha$ - $L$-arabinoside dan cyanidin-3- $\beta-\alpha-$ galactoside (Wollgast dan Anklam, 2000). Procyanidin utama adalah flavan-3,4-diol dengan ikatan 4-8 atau 4-6 membentuk dimer, trimer atau oligomer dengan epicatechin sebagai sub unit utama (Romanczyk et al., 1997 dalam Afoakwa, 2010). Senyawa polifenol pada biji kakao 
tersebut merupakan senyawa antioksidan (Wollgast dan Anklam, 2000).

Antioksidan merupakan senyawa yang dapat menghambat, menunda, atau mencegah reaksi oksidasi baik pada sistem biologis maupun sistem pangan. Reaksi oksidasi disebabkan oleh adanya radikal bebas yang memicu terjadinya reaksi berantai oksidatif. Radikal bebas adalah senyawa berupa atom atau molekul yang memiliki elektron tidak berpasangan pada orbital terluar sehingga bersifat reaktif untuk mencari pasangan. Oksidasi pada bahan pangan disebabkan karena reaksi antara oksigen dengan asam lemak tidak jenuh, protein, karbohidrat atau vitamin (Lee et al., 2004). Oksidasi menyebabkan rusaknya zat gizi dan munculnya aroma yang tidak diinginkan serta senyawa baru hasil oksidasi yang dapat membahayakan kesehatan (Min dan Boff, 2002). Kecepatan oksidasi berbanding lurus dengan tingkat ketidakjenuhan asam lemak. Asam linolenat dengan tiga ikatan rangkap akan lebih mudah teroksidasi daripada asam lemak linoleat dengan dua ikatan rangkap dan oleat dengan satu ikatan rangkap. Oksidasi lemak mendorong terbentuknya peroksida melalui pembentukan hidroperoksida yang selanjutnya mengalami degradasi menjadi senyawa aldehid. Pembentukan aldehid yang mudah menguap menyebabkan bau khas pada lemak yang disebut ketengikan. Mekanisme oksidasi asam lemak yang menghasilkan peroksida lemak dapat terjadi dengan beberapa reaksi yaitu autooksidasi oleh radikal bebas, fotooksidasi, dan reaksi yang melibatkan enzim (Raharjo, 2006).

Reaksi autooksidasi lemak terjadi secara bertahap, yang terdiri dari tahap inisiasi (terjadi pembentukan radikal bebas), propagasi (radikal bebas dirubah menjadi radikal lain) dan terminasi (penggabungan dua radikal membentuk formasi yang stabil) (Gordon, 1990). Mekanisme terjadinya autooksidasi terlihat pada Gambar 1.

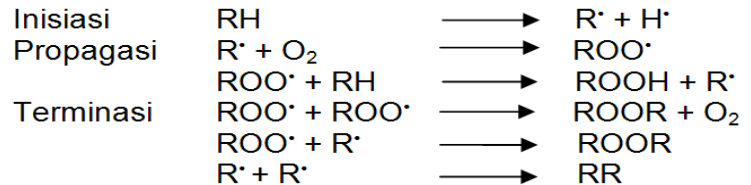

-(radikal), terbentuk dari berbagai jalur termasuk reaksi ${ }^{1} \mathrm{O}_{2}$ (singlet oksigen) dengan asam lemak tidak jenuh atau oksidasi asam lemak tidak jenuh yang dikatalisis oleh lipoksigenase

Gambar 1. Mekanisme autooksidasi (Gordon, 1990)

Tahap inisiasi dapat terjadi karena reaksi langsung antara molekul lipid dengan katalis logam atau karena dekomposisi hidroperoksida yang berasal dari reaksi molekul lipid dengan singlet oksigen atau enzim pengkatalis reaksi molekul lipida dengan triplet oksigen. Ikatan O-O didalam hidroperoksida bersifat lemah, sehingga logam dapat mengkatalisis dekomposisi hidroperoksida menghasilkan radikal bebas. Radikal lipid merupakan spesies yang sangat reaktif sehingga dapat bereaksi dengan molekul lipid lain atau dengan triplet oksigen membentuk radikal lain. Reaksi propagasi biasanya berjalan dengan sangat cepat. Radikal yang terbentuk dapat bereaksi dengan lipid lagi membentuk hidroperoksida yang kemudian masuk dalam tahap inisiasi. Kemudian terjadi tahap terminasi yaitu reaksi penggabungan dua radikal tersebut. Tetapi tahap ini dibatasi oleh rendahnya konsentrasi radikal-radikal (Gordon, 1990).

Proses oksidasi dapat dihambat dengan beberapa metode antara lain mencegah kontak antara bahan pangan dengan oksigen dan cahaya, menambah antioksidan, menyimpan pada suhu rendah, inaktivasi enzim yang mengkatalisis reaksi oksidasi serta penggunaan kemasan (Pokorný et al., 2001; Choe dan Min 2009). Penambahan antioksidan merupakan metode yang banyak digunakan karena relatif mudah dan murah. Penggunaan antioksidan dapat dibedakan dalam sistem biologis dan pangan. Antioksidan dalam sistem biologis, berperan menangkal radikal bebas dalam tubuh sehingga mencegah timbulnya penyakit, seperti kanker, arterosklerosis, 
peradangan, penyakit kardiovaskular dan karies gigi (Ito et al., 2003; Prior dan Gu, 2005). Antioksidan dalam sistem pangan berperan untuk menghambat atau mencegah proses oksidasi lemak sehingga berfungsi sebagai pengawet. Antioksidan dalam sistem pangan didefinisikan sebagai substansi yang mampu menunda, memperlambat atau mencegah terbentuknya ketengikan atau flavor yang tidak dikehendaki karena oksidasi (Pokorný et al., 2001). Antioksidan seperti vitamin, fenol, flavonoid dan proanthocyanidin mampu mencegah berbagai penyakit dan menghambat oksidasi lemak (Shahidi, 2005; Tomaru et al., 2007). Antioksidan alami dapat digunakan untuk menghambat oksidasi bahan pangan. Senyawa antioksidan dapat berfungsi sebagai penangkap radikal bebas, pengkelat ion dan peredam terbentuknya oksigen singlet (Raharjo, 2006).

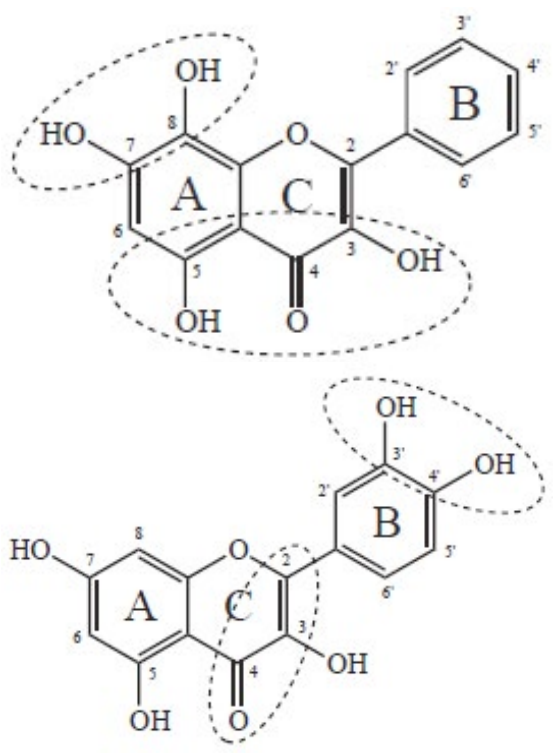

Gambar 2. Struktur flavonoid dengan sisi aktif yang berperan dalam aktivitas antioksidan (Amic et al., 2007).

Antioksidan berdasarkan mekanisme kerjanya dibagi menjadi dua golongan yaitu antioksidan primer dan antioksidan sekunder (Pokorný et al., 2001). Antioksidan primer merupakan senyawa yang dapat menghentikan reaksi berantai pembentukan radikal dengan cara melepaskan hidrogen, sehingga sering disebut pula sebagai donor hidrogen atau scavenger radikal bebas. Antioksidan sekunder mempunyai mekanisme diluar mekanisme pemutusan rantai autooksidasi, dengan mengubah radikal lipid menjadi bentuk yang lebih stabil. Antioksidan sekunder adalah suatu senyawa yang dapat mencegah atau mengurangi laju reaksi inisiasi melalui berbagai mekanisme, misal mengkelat ion atau meredam terbentuknya oksigen singlet. Mekanisme antioksidasi fenolik lebih dominan melalui donor hidrogen. Senyawa fenolik dapat secara cepat bereaksi dengan radikal peroksil sehingga mengakhiri rantai reaksi (Wright et al., 2001 dalam Budhiyanti, 2013). Aktivitas antioksidan fenolik tergantung pada jumlah dan posisi gugus hidroksil dalam hubungannya dengan gugus fungsional karboksil dalam cincin aromatik. Struktur trisiklik flavonoid menentukan efektivitas antioksidan dan kemampuan meredam oksigen reaktif. Cincin aromatik pada flavonoid kakao mampu menetralkan radikal bebas, mengkelat ion $\left(\mathrm{Fe}^{2+}\right.$ dan $\left.\mathrm{Cu}^{+}\right)$, menghambat enzim dan meningkatkan kemampuan antioksidan (Katz et al., 2011). Beberapa penelitian membuktikan polifenol pada kakao mempunyai kemampuan untuk menangkap radikal DPPH, ABTS dan menangkap Reactive Oxygen Species (ROS) (Corcuera et al., 2012). Berdasarkan struktur dan sisi aktif yang berperan pada aktivitas antioksidan senyawa flavonoid kakao ditunjukkan pada Gambar 2.

Kemampuan flavonoid kakao sebagai antioksidan berhubungan dengan strukturnya yang dijelaskan sebagai berikut (Amic et al., 2007): struktur orthodihydroxy 3',4' (catechol) pada cincin B yang memberikan stabilitas terhadap radikal penoksil melalui ikatan hidrogen atau delokalisasi elektron. Struktur catechol pada cincin $\mathrm{B}$ meningkatkan penghambatan peroksida lemak dan berperan dalam menangkap radikal peroksil, superoksida dan peroksinitrit. Senyawa flavonoid tanpa struktur ini mempunyai aktivitas antioksidan yang rendah. Ikatan rangkap C2, C3 dan konjugasi dengan gugus 4-oxo pada cincin C bertanggungjawab terhadap stabilisasi radikal melalui delokalisasi elektron pada ketiga cincin. Keberadaan gugus hidroksil 3 dan 5 yang mampu meningkatkan aktivitas 
antioksidan. Tidak adanya gugus hidroksil pada posisi 3 dalam flavanon dan flavon menurunkan aktivitas antioksidannya. Senyawa yang tidak memiliki struktur orthodihydroxy dalam cincin B tetapi memiliki struktur catechol pada cincin A menunjukkan aktivitas antioksidan yang lebih besar.

Cita rasa khas cokelat dikembangkan pada tahap pengolahan kakao yaitu fermentasi dan penyangraian, dimana pada tahap ini juga banyak terjadi perubahan senyawa antioksidan. Perubahan senyawa antioksidan pada kulit biji kakao antara lain disebabkan karena difusi atau degradasi fenolik selama fermentasi dan penyangraian biji kakao.

Ulasan ini menggunakan metode kajian pustaka dengan mengumpulkan data sekunder dari jurnal ilmiah, buku, hasil penelitian, artikel dan internet yang terkait dengan ulasan ini. Manfaat ulasan ini adalah memberikan informasi sehingga dapat diketahui kondisi proses fermentasi dan penyangraian yang tepat agar aktivitas antioksidan biji kakao dapat dimaksimalkan. Manfaat lain adalah untuk mengembangkan metode atau teknik fermentasi dan penyangraian biji kakao yang dapat meminimalkan penurunan senyawa antioksidan, khususnya untuk memproduksi pangan cokelat fungsional.

\section{Tahap Pengolahan Biji Kakao yang Mempengaruhi Senyawa Antioksidan}

Pengaruh fermentasi dan penyangraian kakao terhadap perubahan antioksidan dapat dijelaskan sebagai berikut:

\section{Pengaruh Fermentasi}

Fermentasi merupakan tahapan penting dalam proses pengolahan kakao yang bertujuan untuk membentuk cita rasa khas cokelat dan mengurangi rasa pahit serta sepat yang ada di dalam biji kakao (Widyotomo dan Mulato, 2008). Tujuan utama fermentasi adalah untuk mematikan biji sehingga terjadi perubahan-perubahan di dalam biji seperti warna keping biji, pembentukan prekursor aroma dan citarasa, serta mempermudah pulp terurai (Afoakwa et al., 2008). Fermentasi yang salah menyebabkan kerusakan citarasa yang tidak dapat diperbaiki melalui modifikasi pengolahan selanjutnya. Biji kakao tanpa fermentasi sama sekali tidak menghasilkan aroma khas cokelat dan memiliki rasa sepat dan pahit yang berlebihan (Misnawi, 2005). Biji kakao tanpa fermentasi mengandung senyawa polifenol yang terdiri dari $37 \%$ catechins, $4 \%$ anthocyanins dan 58\% proanthocyanidins. Total polifenol pada awal fermentasi sebanyak $16,11 \% \quad(b / b)$, dan setelah hari keenam fermentasi menjadi $6,01 \%$ (b/b). Biji kakao Forastero yang tidak difermentasi mengandung polifenol sebanyak 120-180 g/kg (Wollgast dan Anklam, 2000). Konsentrasi awal epicatechin adalah 12 mg/g dan setelah fermentasi hari keenam sebanyak $60 \%$ epicatechin hilang. Kandungan polifenol turun setelah fermentasi disebabkan karena difusi polifenol keluar dari kotiledon selain itu polifenol mengalami oksidasi dan kondensasi (Caligiani etal., 2007). Aktivitas penghambatan radikal DPPH semakin menurun dengan semakin lama fermentasi yang berarti bahwa turunnya aktivitas antioksidan disebabkan karena penurunan polifenol berkurang. Polifenol merupakan komponen utama biji kakao yang berperan terhadap aktivitas antioksidan (Steinberg, 2002). Selama fermentasi, penurunan kandungan polifenol juga disebabkan modifikasi biokimia melalui polimerisasi dan kompleksasi dengan protein. Hal ini juga menyebabkan kelarutan dan rasa sepat berkurang (Bonvehí dan Coll, 1997).

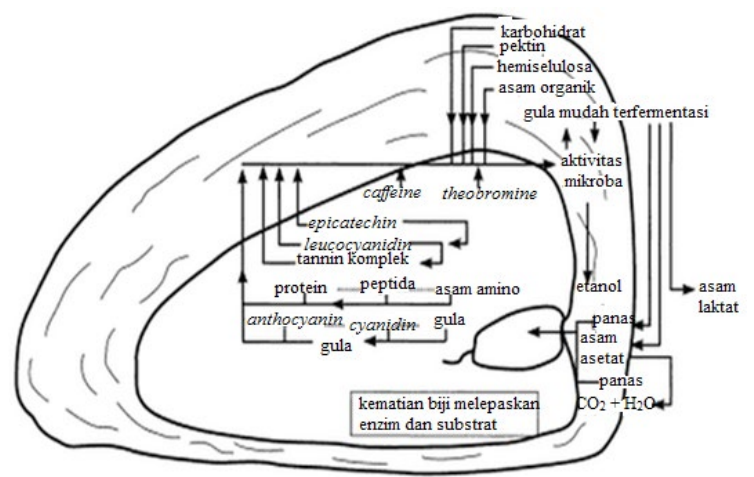

Gambar 3. Perubahan kimia biji kakao selama fermentasi (Lopez dan Dimick, 1995 dalam Wahyudi et al., 2008). 
Selama proses fermentasi, pada pulp, kulit biji dan kotiledon biji kakao terjadi perubahan fisik, biologi serta kimia. Perubahan kimia biji kakao selama fermentasi dapat dilihat pada Gambar 3. Pulp segar memiliki kandungan gula tinggi dan $\mathrm{pH}$ rendah $(3,5)$ karena kandungan asam sitrat. Kondisi ini ideal untuk tumbuhnya mikroorganisme saat biji dikeluarkan dari buah. Kondisibijipada awal fermentasiadalah anaerobik yang tepat untuk pertumbuhan yeast. Yeast merupakan perintis di dalam fermentasi kakao dengan spesies antara lain Saccharomyces cerevisiae, Candida rugosa dan Kluyveromyces marxianus (Schwan, 1998). Yeast mengubah sebagian besar gula dalam pulp menjadi alkohol dan reaksi ini menghasilkan sejumlah besar karbondioksida. Kadar gula yang mulanya sebesar $11 \%$ mengalami metabolisme dan berkurang menjadi $1-2 \%$ selama $24-48$ jam pertama (Anonim, 2013).

Segera setelah proses fermentasi dimulai, pulp terurai kemudian mencair dan menetes keluar. Pulp yang menetes keluar umumnya telah selesai pada 2436 jam pertama fermentasi. Terurainya pulp menyebabkan sebagian asam sitrat berkurang karena mengalir bersama cairan fermentasi. Kondisi ini mengakibatkan peningkatan $\mathrm{pH}$ dan perubahan suhu yang mendorong pertumbuhan bakteri asam laktat. Bakteri asam laktat yang terlibat adalah jenis homofermenter yang mengkonversi glukosa menjadi asam laktat serta heterofermenter yang memproduksi asam laktat dan juga alkohol, asam asetat dan karbondioksida. Bakteri asam laktat pada hari kedua fermentasi sangat dominan dan akan berkurang seiring dengan peningkatan suhu dan kondisi aerobik (Anonim, 2013).

Saat pulp mulai mencair, oksigen yang semula terhalang pulp mengalir ke dalam kotak fermentasi. Kondisi aerob dan $\mathrm{pH}$ pulp yang meningkat menyebabkan bakteri asam asetat mendominasi fermentasi. Bakteri asam asetat mengkonversi alkohol menjadi asam asetat dan memetabolisme asamasam karboksilat seperti asam sitrat, asam malat dan asam laktat menjadi asam asetat. Asam asetat berada pada jumlah maksimum setelah 4-5 hari dan menurun setelahnya. $\mathrm{pH}$ akan meningkat menjadi 4,5-5 karena sejumlah besar asam sitrat hilang dan diganti dengan asam asetat dan asam laktat. Selama aktivitas mikroorganisme ini suhu dalam kotak meningkat mendekati $50^{\circ} \mathrm{C}$. Asam asetat yang semula di permukaan biji merembes lewat kulit biji dan masuk ke dalam kotiledon yang mengakibatkan kematian biji (Anonim, 2013).

Kematian biji selain disebabkan difusi asam asetat juga dipengaruhi difusi etanol dan panas ke dalam biji. Kematian biji akan mempercepat perubahan enzimatis dalam keping biji antara lain rasa sepat berkurang, pigmen ungu hilang, terbentuk warna cokelat serta prekursor flavour dan aroma khas cokelat (Hansen et al., 1998). Penguraian senyawa polifenol, protein dan gula oleh enzim terjadi selama fermentasi sehingga terbentuk prekursor aroma dan rasa pada biji kakao. Biji kakao akan kehilangan daya tumbuh pada hari kedua dimana suhu massa biji naik di atas $40^{\circ} \mathrm{C}$ dan $\mathrm{pH}$ kotiledon turun dari 6,6 menjadi 5. Peningkatan keasaman dikarenakan asam asetat yang dibentuk dalam pulp menembus kulit biji yang kemudian masuk ke dalam kotiledon. Pada biji yang hidup, kulit biji tidak permeabel terhadap asam sitrat yang ada dalam pulp. Kematian biji mengakibatkan permeabilitas sel rusak sehingga senyawa polifenol keluar dari sel dan terdifusi ke seluruh jaringan biji. Akibatnya akan terjadi reaksi dengan enzim polifenol oksidase yang menyebabkan perubahan senyawa polifenol. Epicatechin dan procyanidin dari 3 sub unit atau kurang bersifat larut dan menyebabkan rasa sepat. Molekul yang dibentuk lebih dari 3 sub unit adalah tidak larut dan tidak menyebabkan astringency. Selama fermentasi, konsentrasi polifenol larut berkurang karena oksidasi dan polimerisasi sehingga astringency berkurang dan warna berubah dari ungu menjadi coklat (Ziegleder, 2009).

Epicatechin mengalami polimerisasi membentuk tannin komplek (Forsyth dan Quesnel, 1963 dalam Kim dan Keeney, 1984). Enzim polifenol oksidase mengubah epicatechin menjadi quinon dan diquinon 
(Voigt et al., 1994). Anthocyanin yang menyebabkan warna ungu terhidrolisis menjadi cyanidin dan gula oleh enzim glikosidase. Degradasi anthocyanin menyebabkan perubahan warna dari ungu menjadi coklat. Protein dan peptida membentuk komplek dengan senyawa polifenol menghasilkan warna coklat atau coklat-ungu. Sukrosa diubah oleh invertase menjadi gula reduksi. Protein terhidrolisa oleh enzim peptidase menjadi oligopeptida dan asam amino. Prekursor aroma kakao ini terlibat dalam reaksi Maillard selama penyangraian untuk membentuk senyawa aroma kakao (Beckett, 2009).

Bersamaan dengan berlangsungnya destruksi anthocyanin, terbentuk cairan berwarna coklat dari senyawa flavonoid komplek pada ruang antara kulit biji dan keping biji. Hal inilah yang digunakan sebagai parameter Indeks Fermentasi (IF), dengan nilai berupa rasio antara kadar flavonoid kompleks (coklat) dan kadar anthocyanin (ungu). Indeks fermentasi adalah perbandingan absorbansi pada panjang gelombang $460 \mathrm{~nm}$ (flavonoid kompleks) dan $530 \mathrm{~nm}$ (anthocyanin). Waktu fermentasi yang lebih lama memungkinkan proses destruksi anthocyanin dan pembentukan senyawa berwarna coklat menjadi lebih sempurna sehingga nilai IF lebih tinggi. Penentuan akhir fermentasi dapat diketahui dengan pengamatan $\mathrm{pH}$, suhu dan IF. $\mathrm{pH}$ pulp sebelum fermentasi 3,7-3,9 dan meningkat menjadi 4,8-4,9 diakhir fermentasi. Suhu awal fermentasi adalah $20-25^{\circ} \mathrm{C}$ dan pada akhir fermentasi mencapai $48-50^{\circ} \mathrm{C}$ (Ardhana dan Fleet, 2003). Indikator terjadinya fermentasi sempurna dilihat dari angka IF dimana jika terfermentasi sempurna diperoleh angka IF satu atau lebih. Biji kakao kering yang telah difermentasi memiliki Indeks Fermentasi dengan nilai $I F \geq 1$, sedangkan untuk biji kakao tanpa fermentasi mempunyai nilai IF < 1 (Misnawi, 2005).

Fermentasi berpengaruh terhadap kandungan senyawa antioksidan. Tingginya kandungan polifenol pada kulit biji kakao kemungkinan disebabkan karena waktu fermentasi yang optimal. Fermentasi biji kakao mengakibatkan kematian biji dan permeabilitas sel biji rusak sehingga terjadi difusi senyawa polifenol dari sel pigmen keseluruh bagian kotiledon. Difusi senyawa polifenol mengakibatkan terjadinya kontak dengan enzim polifenol oksidase sehingga mulai terjadi perubahan senyawa polifenol baik kandungan maupun profil polifenol. Polifenol mengalami oksidasi, polimerisasi dan berikatan dengan protein (Bruna et al., 2009). Selama fermentasi, terjadi migrasi epicatechin dari biji kakao ke dalam kulit biji kakao (Roelofsen, 1958; Forsyth dan Quesnel, 1963 dalam Kim dan Keeney, 1984). Sejalan dengan penurunan epicatechin dalam biji pada fermentasi hari kedua dan ketiga, terjadi peningkatan epicatechin di kulit biji kakao. Pada akhir fermentasi (hari ke 6) terjadi penurunan epicatechin baik pada biji maupun kulit biji kakao (Kim dan Keeney, 1984). Biji kakao terfermentasi sempurna mempunyai kandungan epicatechin yang lebih rendah daripada yang terfermentasi sebagian (Kim dan Keeney, 1984; Counet et al., 2004 dalam Bruna et al., 2009). Sedangkan kandungan polifenol kulit biji kakao dari biji kakao yang terfermentasi sempurna lebih tinggi daripada kulit biji kakao dari biji kakao yang terfermentasi sebagian. Semakin lama fermentasi menyebabkan kehilangan polifenol yang lebih besar pada biji kakao (Cruz et al., 2013). Fermentasi 1-6 hari menyebabkan kehilangan polifenol sebesar $63 \%$ dan pada hari ke-6 terjadi penurunan aktivitas antioksidan sebesar $17 \%$ dibanding sebelum fermentasi (Aikpokpodion dan Dongo, 2010). Penurunan senyawa polifenol terutama terjadi pada fraksi monomer catechin dan epicatechin, sebanyak lebih dari $80 \%$ dari nilai awal (Payne et al., 2010). Alkaloid berkurang sebesar $30 \%$ yang disebabkan karena difusi dari kotiledon (Beckett, 2009).

Menurut Wood dan Lass (2001), faktorfaktor yang berpengaruh terhadap fermentasi adalah sebagai berikut :a. Kemasakan buah kakao dimana biji dari buah yang belum matang perkembangannya masih belum kompleks dan pulp yang dihasilkan masih kekurangan gula dimana gula 
merupakan substrat untuk aktivitas mikroba (Yusianto et al., 2008). Misnawi (2005) juga menyebutkan bahwa keberadaan senyawa protein, lemak, polifenol dan aktivitas enzim hanya terdapat pada biji kakao yang sehat dan cukup matang. b. Faktor serangan penyakit pada buah, sebagian besar penyakit yang menyerang buah kakao biasanya menimbulkan kerusakan biji, selain itu buah yang busuk, pecah dan berulat dapat merusak biji sehingga mengganggu berlangsungnya proses fermentasi. c. Rasio pulp/biji berpengaruh terhadap fermentasi dimana biji dengan pulp lebih banyak menghalangi pertukaran udara, menjadikan massa biji lebih anaerob dan kandungan gula yang lebih besar menimbulkan jumlah asam yang lebih banyak pada kotiledon di akhir fermentasi. Pembentukan asam asetat dan kematian biji terjadi lebih lama sehingga fermentasi berjalan lebih lambat. d. Jenis atau tipe kakao, umumnya lama fermentasi adalah 5-7 hari untuk kakao lindak (Forastero) dan 3-4 hari untuk kakao mulia (Criollo) (Susanto, 1994). Waktu fermentasi biji kakao Forastero yang sesuai dengan kondisi lingkungan Indonesia adalah 5 hari (Duncan et al., 1989). Perbedaan lama fermentasi berkaitan dengan kandungan pulp Forastero yang lebih tebal dibandingkan dengan Criollo, bentuk biji kakao Criollo yang lebih pipih dibandingkan dengan Forastero yang lebih tebal serta zat warna ungu pada Criollo lebih sedikit dibandingkan dengan Forastero (Haryadi dan Supriyanto, 2012). e. Faktor yang mempengaruh fermentasi yang lain adalah penundaan pemecahan buah, selisih waktu antara pemanenan dengan pemecahan buah akan menghasilkan peningkatan suhu fermentasi yang lebih cepat sehingga mempercepat fermentasi. Pemeraman buah mampu mempercepat proses fermentasi selama 1 hari. Penyimpanan buah akan mengurangi volume pulp biji kakao yang mengakibatkan terbentuknya ruang antar biji, sehingga oksigen yang tersedia semakin besar yang dapat mendorong terjadinya peningkatan suhu (Anonim, 2013). f. Jumlah biji kakao akan mempengaruhi panas yang timbul selama fermentasi, sehingga berpengaruh terhadap suhu fermentasi. Biji yang terlalu sedikit menyebabkan suhu tidak dapat mencapai $45^{\circ} \mathrm{C}$ sehingga proses fermentasi tidak berjalan optimal.

Setelah fermentasi, terdapat tahapan pengolahan biji kakao yaitu pengeringan, tetapi pengeringan mempunyai efek minimal terhadap perubahan senyawa antioksidan. Epicatechin biji kakao segar sebanyak $12,8 \mathrm{mg} / \mathrm{g}$ dan biji kakao kering sebanyak $12,4 \mathrm{mg} / \mathrm{g}$ sedangkan catechin biji kakao segar sebanyak $0,46 \mathrm{mg} / \mathrm{g}$ tidak mengalami perubahan setelah pengeringan (Payne et al., 2010).

\section{Pengaruh Penyangraian}

Tahapan penyangraian bertujuan untuk mengurangi kandungan air, memudahkan pemisahan kulit biji dari kotiledon serta untuk mengembangkan cita rasa secara optimal. Penyangraian biji kakao dilakukan pada suhu $95-145^{\circ} \mathrm{C}$ (umumnya $110^{\circ}-120^{\circ} \mathrm{C}$ ) sampai kadar air mencapai 1-2\% (de Zaan, 2009). Suhu penyangraian biji kakao berbeda-beda tergantung pada penggunaan produk akhir dan jenis biji. Penyangraian suhu rendah (low roasting) sekitar $110-115^{\circ} \mathrm{C}$ selama 60 menit, penyangraian suhu menengah (medium roasting) sekitar $140^{\circ} \mathrm{C}$ selama 40 menit dan penyangraian pada suhu tinggi (high roasting) pada $190-200^{\circ} \mathrm{C}$ selama 15-20 menit. Produk yang dihasilkan pada penyangraian suhu rendah antara lain lemak kakao dan permen cokelat; suhu menengah antara lain bubuk kakao dan cokelat batang; suhu tinggi antara lain kakao untuk filling dan coating (Minifie, 1989). Suhu penyangraian biji kakao jenis Forastero (lindak) pada 115$140^{\circ} \mathrm{C}$ dan untuk jenis Criollo (mulia) pada suhu $110-115^{\circ} \mathrm{C}$ (Syarief et al., 1988 dalam Mariani 2011).

Derajat penyangraian menyebabkan perubahan senyawa antioksidan. Penyangraian dengan suhu lebih dari $70^{\circ} \mathrm{C}$ menyebabkan kehilangan (+)-catechin tetapi dapat meningkatkan level (-)-catechin karena epimerisasi (-)-epicatechin (Payne et al., 2010). Suhu penyangraian diatas $100^{\circ} \mathrm{C}$ menyebabkan kehilangan flavanol $10 \%$. Semakin tinggi suhu dan waktu penyangraian menyebabkan kehilangan polifenol yang 
lebih besar (Cruz et al., 2013). Payne et al. (2010) menunjukkan bahwa epicatechin turun ketika biji mengalami fermentasi dan penyangraian sampai suhu $120^{\circ} \mathrm{C}$. Total fenolik dan aktivitas antioksidan biji kakao sangrai lebih rendah daripada biji kakao tanpa sangrai (Arlorio et al., 2008).

Protein yang terikat dengan dinding sel (selulosa dan pektin) selama penyangraian akan mengalami reaksi Maillard (Bernaert et al., 2012). Reaksi Maillard adalah reaksi antara gugus amino dari suatu asam amino bebas, residu rantai peptida atau protein dengan gugus karbonil dari suatu karbohidrat apabila keduanya dipanaskan atau disimpan dalam waktu yang relatif lama. Gugus $\in$-amino residu lisin yang terikat pada peptida dan protein berperan penting dalam reaksi karena sangat reaktif. Selain itu gugus a-amino terminal juga berperan dalam reaksi Maillard (Yokotsuka, 1986 dalam Rosida et al., 2007). Produk akhir dari reaksi Maillard yakni melanoidin berpotensi sebagai antioksidan. Sifat antioksidan melanoidin adalah sebagai penangkal radikal bebas dan mampu membentuk struktur redukton (enaminol). Struktur melanoidin mengindikasikan adanya redukton yang mampu mengkelat ion. Melanoidin mempunyai struktur hidroksi piridone atau seperti piranone yang membentuk kompleks dengan ion $\mathrm{Fe}^{3+}$ dan mereduksi aktivitas katalitiknya. Melanoidin mengalami peningkatan selama penyangraian. Produk reaksi Maillard (Maillard Reaction Product/ MRP) juga dapat mencegah oksidasi lipid (Rosida et al., 2007).

Tahapan pengolahan biji kakao yang mempengaruhi perubahan senyawa antioksidan adalah proses fermentasi dan penyangraian. Perubahan senyawa antioksidan pada kulit biji kakao antara lain disebabkan karena difusi atau degradasi fenolik selama fermentasi dan penyangraian biji kakao.

\section{SIMPULAN}

Polifenol utama biji kakao adalah flavanol berupa epicatechin, catechin dan procyanidin. Tahapan pengolahan biji kakao yang mempengaruhi perubahan senyawa antioksidan adalah proses fermentasi dan penyangraian. Fermentasi menyebabkan kandungan polifenol turun karena difusi, oksidasi dan kondensasi. Penyangraian dengan suhu tinggi juga menyebabkan penurunan kandungan polifenol yang disebabkan karena degradasi fenolik. Kajian ini bermanfaat untuk mengetahui proses pengolahan biji kakao yang tepat sehingga aktivitas antioksidan dapat dimaksimalkan. Hal ini dapat dilakukan dengan melakukan fermentasi selama 6 hari dan penyangraian derajat rendah pada $110^{\circ} \mathrm{C}$ selama 60 menit. Kondisi pengolahan kakao tersebut diharapkan dapat menghasilkan biji kakao dengan cita rasa baik dan mempunyai aktivitas antioksidan yang tinggi.

\section{DAFTAR PUSTAKA}

Afoakwa, E. O., A. Paterson, M. Fowler, and A. Ryan. 2008. Flavor Formation and Character in Cocoa and Chocolate: A Critical Review.Journal Critical Reviews in Food Science and Nutrition 48 (9): 840-57. doi:https://doi. org/10.1080/10408390701719272.

Afoakwa, E.O. 2010. Chocolate Science and Technology. 1sted. United Kingdom: Wiley-Blackwell, John Wiley \& Sons Ltd. doi:10.1002/9781444319880.

Aikpokpodion, P. E., and L. N. Dongo. 2010. Effects of Fermentation Intensity on Polyphenols and Antioxidant Capacity. Int. J. Sustain. Crop Prod. 5 (4): 66-70.

Amic, D., D. Davidovic-Amic, D. Beslo, V. Rastija, B. Lucic, and N. Trinajstic. 2007. SAR and QSAR of the Antioxidant Activity of Flavonoids. Current Medicinal Chemistry 14 (7): 827-45. doi:10.2174/092986707780090954.

Andres-Lacueva, C., M. Monagas, N. Khan, M. Izquterdo-Pulido, M. Urpi-Sarda, J. Permanyer, and R. M. LamuelaRaventós. 2008. Flavanol and Flavonol Contents of Cocoa Powder Products: Influence of the Manufacturing Process.Journal of Agricultural and Food Chemistry 56 (9): 3111-17. doi:10.1021/jf0728754. 
Anonim. 2013. Pasca Panen, Kualitas Biji Kakao Dan Fermentasi. Medan: Swisscontact. https://www. swisscontact.org/fileadmin/user. upload/COUNTRIES/Indonesia/ Documents/Publications.

Arlorio, M., M. Locatelli, F. Travaglia, J. D. Coïsson, E. D. Grosso, A. Minassi, G. Appendino, and A. Martelli. 2008. Roasting Impact on the Contents of Clovamide (N-Caffeoyl-L-DOPA) and the Antioxidant Activity of Cocoa Beans (Theobroma Cacao L.).Food Chemistry 106 (3): 967-75. doi:10.1016/j. foodchem.2007.07.009.

Beckett, S.T. 2009. Traditional Chocolate Making. In Industrial Chocolate Manufacture and Use, $4^{\text {th }}$ ed., 1-9. United Kingdom: Wiley-Blackwell, John Wiley \& Sons Ltd.

Bernaert, H., I. Blondeel, L. Allegaert, and T. Lohmueller. 2012. Industrial Treatment of Cocoa in Chocolate Production: Health Implications. In Chocolate and Health, edited by R. Paoletti, A. Poli, A. Conti, and F. Visioli, 17-32. Italia: Springer.

Bonvehí, J. S., and F.V. Coll. 1997. Evaluation of Bitterness and Astringency of Polyphenolic Compounds in Cocoa Powder. Food Chemistry 60 (3): 365-70. doi:10.1016/S03088146(96)00353-6.

Bruna, C., I. Eichholz, S. Rohn, L. W. Kroh, and S. Huyskens-Keil. 2009. Bioactive Compounds in Cocoa Hulls (Theobroma Cacao L.) from Different Origins. Journal of Applied Botany and Food Quality.

Budhiyanti, S. A. 2013. Karakterisasi Dan Identifikasi Antioksidan Dari Rumput Laut Coklat Sargassum Sp. Sebagai Antioksidan Dalam Mikroemulsi W/O. Universitas Gadjah Mada.

Caligiani, A., M. Cirlini, G. Palla, R. Ravaglia, and M. Arlorio. 2007. GC-MS Detection of Chiral Markers in Cocoa Beans of Different Quality and Geographic Origin. Chirality 19 (4): 329-34. doi:10.1002/chir.20380.
Choe, E., and D. B. Min. 2009. Mechanisms of Antioxidants in the Oxidation of Foods. Comprehensive Reviews in Food Science and Food Safety 8 (4): 345-58. doi:10.1111/j.15414337.2009.00085.x.

Corcuera, L. A., S. Amézqueta, L. Arbillaga, A. Vettorazzi, S. Touriño, J. L. Torres, and A. López de Cerain. 2012. A Polyphenol-Enriched Cocoa Extract Reduces Free Radicals Produced by Mycotoxins. Food and Chemical Toxicology 50 (3-4). Elsevier Ltd: 98995. doi:10.1016/j.fct.2011.11.052.

Cruz, J. F. M., P. B. Leite, S. E. Soares, and E. S. Bispo. 2013. Assessment of the Fermentative Process from Different Cocoa Cultivars Produced in Southern Bahia, Brazil. African Journal of Biotechnology 12 (33): 5218-25. doi:10.5897/AJB2013.12122.

de Zaan. 2009. Cocoa \& Chocolate Manual. Manual. 40 th Anniv. ADM Cocoa. https:// www.choklat.com/data/documents/ dezaancocoamanual.pdf.

Duncan, R. J. E., G. Godfrey, T. N. Yap, G. L. Pettipher, and T. Tharumarajah. 1989. Improvement of the Malaysian Cocoa Bean Flavour by Modification of Harvesting , Fermentation and Drying Methods - the Sime-Cadbury Process. The Planter 65: 157-74.

Gordon, M. H. 1990. The Mechanism of Antioxidant Action in Vitro. In Food Antioxidants, edited by Hudson B.J.F., 1sted., 1-18. United Kingdom: Elsevier Applied Food Science Series. Springer, Dordrecht. doi:https://doi. org/10.1007/978-94-009-0753-9_1.

Hansen, C. E., M. Del Olmo, and C. Burri. 1998. Enzyme Activities in Cocoa Beans during Fermentation. Journal of the Science of Food and Agriculture 77 (2): 273-81. doi:10.1002/(SICI)1097$0010(199806) 77: 2<273::$ AID JSFA40>3.0.CO;2-M.

Haryadi, dan Supriyanto. 2012. Teknologi Cokelat. Yogyakarta: UGM Press.

Ito, K., Y. N. Akamura, T. T. Okunaga, and D. I. ljima. 2003. Anti Cariogenic Properties 
of a Water Soluble Extract from Cacao. Enzyme 67 (12): 2567-73.

Katz, D. L., K. Doughty, and A. Ali. 2011. Cocoa and Chocolate in Human Health and Disease.Antioxidants \& Redox Signaling 15 (10): 2779-2811. doi:10.1089/ars.2010.3697.

Kim, H., and P.G. Keeney. 1984. (-)-Epicatechin Content in Fermented and Unfermented Cocoa Beans. Journal of Food Science 49 (4): 109092. https://onlinelibrary. wiley.com/ doi/abs/10.1111/j.1365-2621.1984. tb10400.x.

Lau-Cam, C. A. 2013. The Absorption, Metabolism, and Pharmacokinetics of Chocolate Polyphenols. In Chocolate in Health and Nutrition, edited by Sherma Watson, Ronald, Preedy, Victor R., Zibadi, 1sted., 201-46. London: Humana Press. doi:10.1007/978-161779-803-0.

Lee, J., N. Koo, and D. B. Min. 2004. Reactive Oxygen Species, Aging, and Antioxidative Nutraceuticals. Comprehensive Reviews in Food Science and Food Safety 3 (1): $21-$ 33. doi:10.1111/j.1541-4337.2004. tb00058.x.

Loppies, J. E., dan M. Yumas. 2008. Mempelajari Proses Fermentasi Biji Kakao Dengan Penambahan Aktivator. Jurnal Industri Hasil Perkebunan 3 (1): 25-32.

Mariani, L. 2011. Ekstraksi Dan Identifikasi Senyawa Polifenol Dalam Kulit Biji Kakao Dan Potensinya Sebagai Antioksidan. Universitas Gadjah Mada. http://etd.repository.ugm. ac.id /index.php?mod= penelitian detail \& sub $=$ PenelitianDetail \& act=view\&typ=html\&buku id $=53068$.

Min, D. B., and J. M. Boff. 2002. Chemistry and Reaction of Singlet Oxygen in Foods. Comprehensive Reviews in Food Science and Food Safety 1 (2): 58-72. doi:10.1111/j.1541-4337.2002. tb00007.x.

Minifie, B.W. 1989. Chocolate, Cocoa and Confectionery: Science and
Technology. $3^{\text {rd }}$ ed. Maryland: Chapman and Hall.

Misnawi. 2005. Peranan Pengolahan Terhadap Pembentukan Citarasa Cokelat. Warta Pusat Penelitian Kopi Dan Kakao 21 (3).

Payne, M. J., W. J. Hurst, K. B. Miller, C. Rank, and D. A. Stuart. 2010. Impact of Fermentation, Drying, Roasting, and Dutch Processing on Epicatechin and Catechin Content of Cacao Beans and Cocoa Ingredients. Journal of Agricultural and Food Chemistry 58 (19). Chemistry Central Ltd: 10518-27. doi:10.1021/jf102391q.

Pokorný, J., N. Yanishlieva, and M. Gordon. 2001. Antioxidants in Food: Practical Applications. London: Woodhead Publishing.

Prior, R. L., and L. Gu. 2005. Occurrence and Biological Significance of Proanthocyanidins in the American Diet. Phytochemistry 66 (18 SPEC. ISS.): 2264-80. doi:10.1016/j. phytochem.2005.03.025.

Raharjo, S. 2006. Kerusakan Oksidatif Pada Makanan. $1^{\text {sted. }}$ Yogyakarta: UGM Press. http://ugmpress.ugm.ac.id/id/ product/pertanian/kerusakan-oksidatifpada-makanan.

Roelofsen, P. A. 1958. Fermentation, Drying, and Storage of Cacao Beans.Advances in Food Research 8 (C): 225-96. doi:10.1016/S0065-2628(08)60021-X.

Rosida, D.F., D. Fardiaz, A. Apriyantono, dan N. Andarwulan. 2007. Isolasi Dan Karakterisasi Melanoidin Kecap Manis Dan Peranannya Sebagai Antioksi dan. Jurnal Teknologi Dan Industri Pangan XVII (3): 204-5.

Schwan, R. F. 1998. Cocoa Fermentations Conducted with a Defined Microbial Cocktail Inoculum.Applied and Environmental Microbiology 64 (4): 1477-83. doi:10.1017/ CBO9781107415324.004.

Shahidi, F. 2005. Nutraceuticals and Functional Foods in Health Promotion and Disease Risk Reduction.Acta Horticulture 6: 13-24. 
Steinberg, M.K. 2002. The Globalization of a Ceremonial Tree: The Case of Cacao (Theobroma Cacao) among the Mopan Maya. Economic Botany 56 (1): 58-65. https://www.jstor.org/stable/4256520.

Susanto, F.X. 1994. Tanaman Kakao: Budidaya Dan Pengolahan Hasil. Yogyakarta: Kanisius. http://search. jogjalib.com/Record/kulonprogolibPROGO-/Details.

Tomaru, M., H. Takano, N. Osakabe, A. Yasuda, K. I. Inoue, R. Yanagisawa, T. Ohwatari, and H. Uematsu. 2007. Dietary Supplementation with Cacao Liquor Proanthocyanidins Prevents Elevation of Blood Glucose Levels in Diabetic Obese Mice. Nutrition 23 (4): 351-55. doi:10.1016/j. nut.2007.01.007.

Voigt, J., H. Heinrichs, G. Voigt, and B. Biehl. 1994. Cocoa-Specific Aroma Precursors Are Generated by Proteolytic Digestion of the Vicilinlike Globulin of Cocoa Seeds. Food Chemistry 50 (2): 177-84. doi:10.1016/0308-8146(94)90117-1.

Wahyudi, T., T. R. Panggabean, dan Pujiyanto. 2008. Panduan Lengkap Kakao. Jakarta: Penebar Swadaya.

Widyotomo, Sukrisno, dan Sri Mulato. 2008. Fermentation Technology and Cocoa Pulp Diversification Product to Increase Good Quality and Added Value. Review Peneitian Kopi Dan Kakao 24 (1): 65-82.
Wollgast, J., and E. Anklam. 2000. Review on Polyphenols in Theobroma Cacao: Changes in Composition during the Manufacture of Chocolate and Methodology for Identification and Quantification.Food Research International 33 (6): 423-47. doi:10.1016/S0963-9969(00)00068-5.

Wood, G.A.R., and R.A. Lass. 2001. Cocoa. United Kingdom: Wiley-Blackwell, John Wiley \& Sons Ltd. https: //www. wiley.com/en-us/Cocoa\%2C + 4th + Edition-p-9780632063987.

Yusianto, T. Wahyudi, dan Sulistyowati. 2008. Pasca Panen. Dalam Panduan Lengkap Kakao Managemen Agribisnis Dari Hulu Hingga Hilir, editor T. Wahyudi, R. Panggabean, dan Pujiyanto, 207. Jakarta: Penebar Swadaya.

Ziegleder, G. 2009. Flavour Development in Cocoa and Chocolate. In Industrial Chocolate Manufacture and Use: Fourth Edition, edited by S.T. Beckett, $4^{\text {th }}$ ed., 169-91. United Kingdom: WileyBlackwell, John Wiley \& Sons Ltd. doi: 10.1002/9781444301588. 